\title{
PENGARUH MEDIA TANAM TERHADAP RESPON FISIOLOGI AKLIMATISASI ANGGREK Cattleya
}

\author{
V. Andriani ${ }^{1}$ dan I.A.K.Pramushinta ${ }^{2}$ \\ Jurusan Biologi, FMIPA, Universitas PGRI Adi Buana Surabaya \\ E-mail: vivin.andriani@yahoo.com \\ intanakpe@yahoo.com
}

\begin{abstract}
Cattleya included in the family Orchidaceae that can be grown using tissue culture methods. Adjustments to the climate into a new environment, known as acclimatization is an important issue when cultivating the plant seedlings are propagated by tissue culture techniques. This study aims to determine the acclimatization media (wood charcoal, husk charcoal, moss and cocopeat ) suitable for a physiological response (weight of the plant and chlorophyll content) Cattleya tissue culture results. Measurement of chlorophyll content using a spectrophotometer. Results obtained in the form of quantitative. Data analysis using ANAVA with SPSS 16 Software. Results showed that rice husk media has a great influence over the weight and chlorophyll content acclimatization Cattleya.
\end{abstract}

Keywords: Cattleya, Acclimatization, Media

\section{PENDAHULUAN}

Anggrek merupakan tanaman hias yang memiliki bunga dengan warna indah, dalam penggolongan taksonomi termasuk famili Orchidaceae, suatu famili yang memiliki ciri - ciri antara lain, mempunyai akar rimpang atau batang yang membesar, daun tidak bertangkai, sepenuhnya duduk pada batang, bagian tepi tidak bergerigi, tulang daun sejajar dengan tepi daun, susunannya berselang-seling atau berhadapan, bunga berkelamin dua dan bunga memiliki lima bagian utama yaitu sepal (daun kelopak), petal (daun mahkota), stamen (benang sari), pistil (putik), dan ovari (bakal buah). (Van Stenis, 2008 ).

Cattleya termasuk salah satu jenis anggrek yang epifit dan memiliki pseudobulb tebal sehingga dapat menyimpan banyak air dan cadangan makanan (Arditti, 2010).

Penyesuaian terhadap iklim pada lingkungan baru yang dikenal dengan aklimatisasi merupakan masalah penting apabila membudidayakan tanaman menggunakan bibit yang diperbanyak dengan teknik kultur jaringan (Dwiyani, 2012). Pada saat proses aklimatisasi memerlukan kondisi yang khusus lingkungan terutama media tanam, suhu, kelembaban, dan intensitas cahaya (Zulkarnain, 2009).

Media tanam terdiri atas dua yaitu media tanam organik dan anorganik. Media tanam organic mempunyai pori-pori mikro dan makro yang seimbang, sehingga mempunyai sirkulasi udara dan daya serap air yang baik. Media organik antara lain arang kayu, srang sekam, moss, dan cocopeat (Rossa et al., 2011).

Arang kayu mengandung karbon, sulfur, fosfor dan abu. sifat lain dari media ini adalah tahan lama, daya mengikat air kurang, cocok di pakai di daerah yang mempunyai kelembaban lingkungan yang tinggi. Kandungan karbon yang tinggi dapat merangsang pertumbuhan akar tanaman (Komarayati dan Santoso, 2011).

Arang sekam terdapat karbon, fosfor, dan sulfur dan abu. Sifat arang sekam memiliki banyak rongga dapat digunakan sebagai drainase dan aerasi yang baik, sehingga akar tanaman mudah bergerak diantara butiran arang sekam (Livy Winata, 2006).

Moss mengandung nitrogen dan fosfor. Media ini berasal dari paku-pakuan atau kadaka. Moss memiliki beberapa kelebihan antara lain: dapat menyerap dan mempertahankan air serta pupuk dengan baik serta menjaga kelembaban. Kadungan nitrogen dan fosfor berfungsi merangsang pertumbuhan dan mempecepat pembungaan (Benyy, 2007).

Cocopeat mengandung kalium, magnesium, kalsium, nitrogen, dan fosfor. Media ini berasal dari sabut kelapa. Kandungan pada media ini dapat membantu pertumbuhan tanaman mulai dari akar dan daun (Raffli dan Zulman, 2011).

Pada penelitian ini dilakukan proses aklimatisasi anggrek Cattleya dengan beberapa media tanam (arang kayu, arang sekam, moss, dan cocopeat serta diperlakukan di dalam plenty. Untuk mengetahui respon fisiologi (berat dan kadar klorofil) pada anggrek Catteya tersebut.

\section{MATERI DAN METODE PENELITIAN}

Penelitian dilaksanakan di green house dan labolatorium dasar Prodi Biologi FMIPA Universitas PGRI Adi Buana Surabaya. Sampel yang digunakan adalah anggrek Cattleya yang berumur 6 bulan, sampel yang digunakan 40 
sampel. Data yang di ambil adalah berat dan kadar klorofil daun.

\section{Kadar Klorofil Daun}

Penentuan kadar klorofil daun dilakukan pada hari ke 30 setelah perlakuan dan diukur dengan metode spektrofotometri. Sampel daun tiap perlakuan ditimbang $0,1 \mathrm{~g}$, digerus dengan mortal dan ditambah aseton dan disaring dengan kertas saring. Filtrat dipindah dalam labu ukur $10 \mathrm{ml}$ dan ditambahkan aseton $80 \%$ hingga volume $10 \mathrm{ml}$, selanjutnya dimasukkan ke dalam kuvet dan diukur absorbansinya menggunakan spektrofotometer dengan panjang gelombang 645 dan 663 nm. Kadar klorofil total di hitung dengan rumus:

Kadar klorofil total $=((20,2 \times$ D645 $)+(8,02 \times$ D663 $)) \times$ 0,1

Pelakuan dilakukan dengan media tanam antara lain: Arang Kayu (A), Arang Sekam (B), Moss (C), dan Cocopeat (D).

\section{HASIL PENELITIAN DAN PEMBAHASAN}

Dari penelitian diatas didapatkan data berat Anggrek dan kadar klorofil Cattleya selama 30 hari setelah perlakuan pada grafik 1 dan 2 :

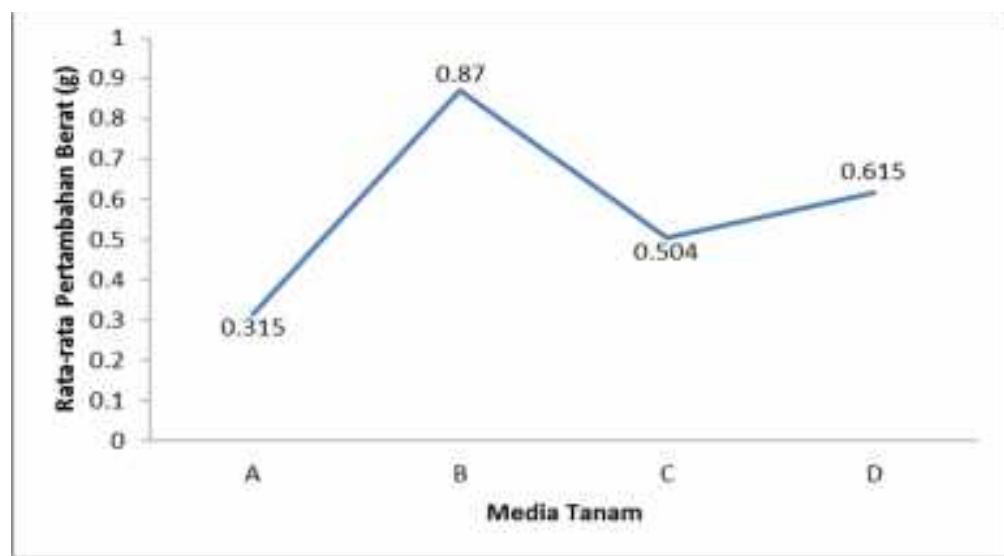

Gambar 1. Rata-rata berat Anggrek Cattleya (g)

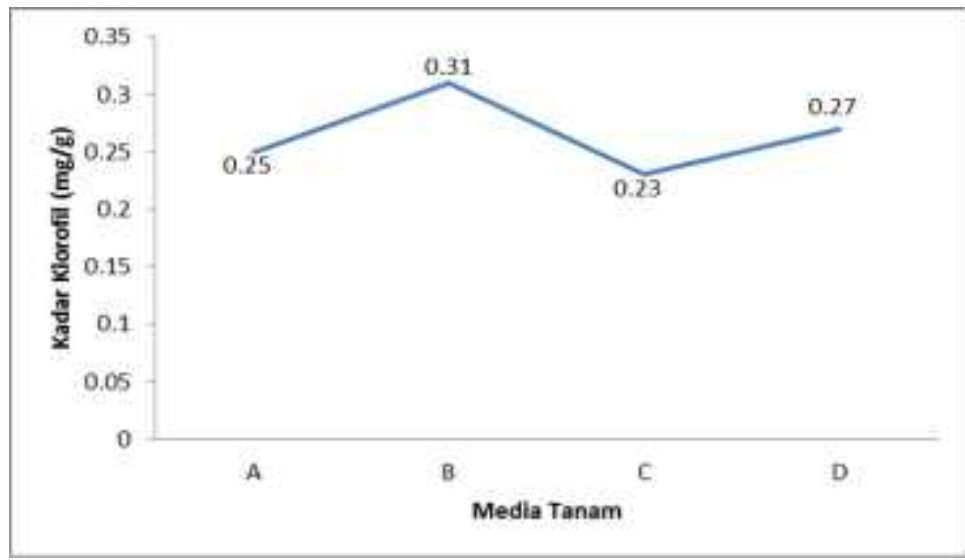

Gambar 2. Kadar Klorofil Daun.

Pada table dan grafik diatas dapat dilihat bahwa berat tanaman dan kadar klorofil daun paling besar pada perlakuan media arang sekam. Pada media tersebut mempunyai banyak kelebihan sebagai media tanaman dari tekstur yang memiliki banyak rongga yang dapat mempengaruhi drainase dan aerasi. Butiran-butiran arang sekam dapat mempermuda gerakan akar. Kandungan karbon, sulfur dan fosfor pada arang sekam berfungsi mempercepat pertumbuhan akar dan tinggi tanaman (Sofyan et al, 2007).
Kadar klorofil pada tanaman dipengaruhi oeleh intensitas cahaya dan volume air. Maka drainase dan aerasi berperan dalam pembentukan klorofil. Air berperan dalam menyediakan molekul oksigen untuk proses akumulasi dan konversi glutamate menjadi ALA (5-aminolevilinium acid) dan menciptakan suatu kondisi aerob untuk mengkonversi senyawa intermediet Mg-Proto menjadi Pchlide (Liu et al., 2013). Dengan struktur arang sekam yang mempunyai drainase dan aerasi yang baik maka dapat menciptakan kondisi yang baik untuk biosintesis klorofil. 


\section{DAFTAR PUSTAKA}

Arditti, J. 2010. Plenary Presentation : History of Orchid Propagation. AsPac J.Mol. Biol.Biotecnol. Vol 18 (1) Supplement : 171174.

Dwiyani, R. 2012. Respon Pertumbuhan Bibit Anggrek Dendrobium sp. Pada Saat Aklimatisasi terhadap Beragam Frekuensi Pemberian Pupuk Daun. Agrotrop. Bali.

Komarayati, S. dan E. Santoso. 2011. Arang dan cuka kayu : Produk HHBK untuk stimulant pertumbuhan mengkudu (Morinda citrifolia). Jurnal Penelitian Hasil Hutan 29 (2) :155178. Puslitbang Keteknikan Kehutanan dan Pengolahan Hasil Hutan. Bogor.

Liu, X., Chen, C-Y., Wang, K.C., Luo, M., Tai, R., Yuan, L., Zhao, M., Yang, S., Tian, G., Cui, Y., Hsieh, H.L., and Wu, K. 2013. Phytochrome interacting factor3 associates with thehistone deacetylase hda15 in repression of chlorophyll biosynthesis and photosynthesis in etiolated Arabidopsis seedlings. The Plant Cell. 25 : 1258-1273.

Livy Winata Gunawan. 2006. Budidaya anggrek. Penebar swadaya. Jakarta
Van Steenis. 2008. Flora, Cetakan ke-12. Jakarta: PT. Pradnya Paramita.

Rafli Munir, dan Zulman H.U. 2011. Pengaruh Berbagai Media Dengan Inokulan Mikoriza Terhadap Aklimatisasi Anggrek Dendrobium (Dendrobium sp) (Effect of Various Media with Mycorrhizal Inoculant on Dendrobium Orchid Acclimatization (Dendrobium Sp)). Jerami Volume 4 No.2 ISSN 1979-0228.

Rossa Yunita, Endang dan Gati Lestarai. 2011. Perbanyakan Tanaman Pulai Pandak (Rauwolfia serpentina L.) dengan Teknik Kultur Jaringan. Jurnal Natur Indonesia 14(1): 68-72 ISSN 1410-9379, Keputusan Akreditasi No 65a/DIKTI/Kep./2008.

Sofyan SE, Riniarti M, Duryat. 2014. Pemanfaatan limbah teh, sekam padi, dan arang sekam sebagai media tumbuh bibit trembesi (Samanea saman). Jurnal Sylva Lestari 2 (2): 61-70.

Zulkarnain. 2009. Kultur Jaringan Tanaman; Solusi Perbanyakan Tanaman Budi Daya. Bumi Aksara, Jakarta. 